\title{
Comparative Studies on the Fecundity, Egg Survival, Larval Feeding, and Development of Chilo partellus and Chilo orichalcociliellus (Lepidoptera: Crambidae) on Five Grasses
}

\author{
V. C. OFOMATA, ${ }^{1}$ W. A. OVERHOLT,${ }^{1}$ S. A. LUX, ${ }^{1}$ A. VAN HUIS,${ }^{2}$ and R. I. EGWUATU ${ }^{3}$
}

\begin{abstract}
Ann. Entomol. Soc. Am. 93(3): 492-499 (2000)
ABSTRACT Chilo partellus (Swinhoe) and Chilo orichalcociliellus Strand (Lepidoptera: Crambidae) are gramineous stem borers that occur sympatrically in the southern coastal area of Kenya. Evidence over a 30-yr period indicates that the indigenous stem borer, C. orichalcociliellus, is being gradually displaced by the exotic stem borer, C. partellus. Comparative laboratory studies were conducted in several large-stemmed grasses to examine factors that may be involved in the displacement of C. orichalcociliellus, and to examine other possible effects of the invasion of C. partellus into Kenya. C. partellus had a higher fecundity than C. orichalcociliellus at 25 and $28^{\circ} \mathrm{C}$, but not at $31^{\circ} \mathrm{C}$. In addition, more C. partellus than C. orichalcociliellus eggs survived to the first instar. C. partellus larvae developed faster than $C$. orichalcociliellus in maize and sorghum. In this shorter developmental time, C. partellus consumed more maize than C. orichalcociliellus, but both species consumed equal amounts of sorghum. On a daily basis, C. partellus consumed more maize and sorghum than C. orichalcociliellus. A few C. orichalcociliellus survived to the pupal stage in napier and guinea grasses, whereas no C. partellus survived. The shorter developmental period of C. partellus may give this species a competitive advantage over the slower developing $C$. orichalcociliellus. However, the ability of $C$. orichalcociliellus to complete development in two native grasses in which C. partellus did not survive may provide a refuge that has allowed C. orichalcociliellus to escape extirpation from the coastal area of Kenya.
\end{abstract}

KEY WORDS Chilo partellus, Chilo orichalcociliellus, competitive displacement, adult fecundity, egg survival, larval development

Chilo partellus (SwinHoe), an Asian species that invaded Africa sometime before 1930 (Tams 1932), and the indigenous Chilo orichalcociliellus Strand are gramineous stem borers that attack maize and sorghum in East Africa. These two stem borers, along with one other native species, Sesamia calamistis Hampson (Lepidoptera: Noctuidae), have overlapping distributions in the southern coastal area of Kenya and are often found together in the same maize and sorghum fields (Mathez 1972; Warui and Kuria 1983; Overholt et al. 1994). Following the invasion of C. partellus into Kenya in the early 1960s (Nye 1960), evidence has accumulated that C. orichalcociliellus is being gradually displaced at the Kenya Coast. Mathez (1972) sampled maize and sorghum in the coastal area from 1965 to 1969 and found that C. orichalcociliellus was the dominant species, accounting for $\approx 60 \%$ of the stem borers collected. C. partellus was the second most common species with $\approx 30 \%$ of the total population, and S. calamistis was considered to be of minor importance. In the period 1978-1981, Warui and Kuria (1983) found that C. orichalcociliellus and C. partellus

\footnotetext{
${ }^{1}$ International Centre of Insect Physiology and Ecology (ICIPE), Box 30772, Nairobi, Kenya.

${ }^{2}$ Department of Entomology, Wageningen Agricultural University, The Netherlands.

${ }^{3}$ Department of Biological Sciences, Nnamdi Azikiwe University, Awka, Anambra State, Nigeria.
}

were nearly equally abundant in maize and sorghum, and that S. calamistis was much less common. However, in 1991-1992 in the same area, C. partellus accounted for $>80 \%$ of the stem borers, with both $C$. orichalcociliellus and S. calamistis being of minor importance (Overholt et al. 1994). The average number of stem borers per plant found in the three studies were approximately the same. In Mathez's (1972) study there were $0.8-2.3$ stem borers per plant, Warui and Kuria (1983) found 0.7-1.4, and Overholt et al. (1994) found 0.2-1.8. Thus, although total stem borer numbers in the southern coastal area of Kenya do not appear to have increased since the invasion of $C$. partellus, the exotic species has become relatively more abundant.

Previous studies revealed that C. partellus and C. orichalcociliellus have similar biologies, resource requirements, and are affected by the same natural and physical mortality factors (Mathez 1972, Delobel 1975). However, no matter how closely related, species exhibit differences in their biological attributes, which may influence the outcome of competitive interactions under a given set of conditions. For instance, differences may occur in their fecundity, longevity, development, or survival. Ultimately, the species that has the highest effective progeny production will win under a given set of conditions. Effective progeny production is based on total fecundity, sex 
ratio, survival to reproduction, and time required for development to reproductive maturity (Debach and Sundby 1963). All these parameters may be modified by a variety of environmental conditions such as temperature, humidity, food quality, or quantity and interspecific competition.

The fecundities of C. partellus and C. orichalcociliellus were reported to be approximately equal, with $C$. partellus ovipositing a mean of 434 eggs (Berger 1989) and C. orichalcociliellus ovipositing a mean of 475 eggs (Delobel 1975). Mbapila (1997) compared the fecundities and egg viability of C. partellus and C. orichalcociliellus reared on maize at different temperatures. He reported the fecundity and egg viability of $C$. partellus were higher than those of C. orichalcociliellus at all temperatures except $31^{\circ} \mathrm{C}$. However, in addition to cultivated grasses, several wild grasses are attacked by C. partellus and C. orichalcociliellus (Mathez 1972, Seshu Reddy 1989, Khan et al. 1997). The quality and quantity of these plants for the development and survival of stem borers is likely to vary owing to differences in their morphology, physiology, and biochemistry.

Comparative laboratory investigations on the development of C. partellus and C. orichalcociliellus on an artificial diet revealed that C. partellus completed a generation in a shorter time than $C$. orichalcociliellus (Kioko et al. 1995). Mbapila (1997) compared the developmental times of C. partellus and C. orichalcociliellus in maize and also found that C. partellus completed a generation in a shorter time than C. orichalcociliellus. Information on the development of $C$. partellus and C. orichacociliellus on other host plants may be useful in explaining recent changes in the population densities of these stem borer species.

Apart from displacing an indigenous species, other effects of the invasion of C. partellus into Kenya are unknown. One question is whether damage to crops has increased, decreased, or remained about the same since the invasion. Before the arrival of C. partellus in Kenya, C. orichalcociliellus was considered to be an important pest of cereal crops (Mathez 1972, Warui and Kuria 1983). Although it is not possible to compare crop losses before and after the arrival of C. partellus because of inadequate historical records, laboratory feeding trials may provide some insight. In the current study we compared the fecundity, egg survival, and larval development of C. partellus and C. orichalcociliellus in various host plants as potential factors involved in the displacement of $C$. orichalcociliellus. Consumption by larvae of the two stem borers on maize and sorghum also was compared to provide a possible indication of plant damage.

\section{Materials and Methods}

Fecundity and Egg Survival. Fresh pupae of C. partellus and C. orichalcociliellus originating from larvae reared on an artificial diet (Ochieng et al. 1985) for several generations were obtained from laboratory cultures maintained at the International Center of Insect Physiology and Ecology in Nairobi, Kenya.
Field-collected stem borers were added to the laboratory cultures of both species several times during the year to maintain genetic diversity. Newly emerged male and female pairs of the two moth species were held singly in square-shaped, $20-\mathrm{cm}^{3}$ wire mesh oviposition cages. The insides of the cages were lined with crumpled waxed paper as a removable oviposition substrate. C. partellus and C. orichalcociliellus are known to oviposit readily on this substrate (Delobel 1975, Kumar and Saxena 1985). Experiments were conducted in incubators under all possible combinations of three constant temperatures of 25,28 , and $31^{\circ} \mathrm{C}$ and three relative humidities of 75,84 , and $96 \%$ with a photoperiod of 12:12 (L:D) h. Each treatment included 100 pairs of C. partellus and C. orichalcociliellus, except that for all temperatures in the $75 \% \mathrm{RH}$ treatment for $C$. orichalcociliellus, only 50 pairs were used because of an inadequate supply. Each pair of moths was provided with a cotton ball saturated with a $20 \%$ sugar-water solution (wt:vol) to provide nourishment for the moths. The waxed papers were removed and examined daily for eggs. Egg batches from each female were cut from the waxed papers the day after they were laid, counted, and kept under the same controlled environments in glass vials $7.5 \mathrm{~cm}$ by $2.5 \mathrm{~cm}$. Observations on each pair were terminated when the female died. Mean fecundity was compared between temperatures and relative humidities using analysis of variance (ANOVA) (PROC GLM) and means were separated using the Student-Newman-Keul multiple range test (SAS Institute 1988).

Individual egg batches were examined daily until the black-head stage when the number of fertile eggs could be determined. The numbers of larvae hatching from eggs were recorded. Proportional data were arcsine square root transformed and treatments compared using ANOVA to determine differences in percentage egg fertility and hatchability. Means were separated using the Student-Newman-Keuls multiple range test (SAS Institute 1988).

Food Consumption by Larvae. First instars of $C$. partellus and C. orichalcociliellus were fed individually on tender whorl tissues of maize (variety Katumani) and sorghum seedlings (variety Serena). Both varieties are known to be susceptible to C. partellus and are often used as susceptible checks in host plant resistance screening trials (Alghali 1985, Ampofo et al. 1986). The plants used in the study were grown in a small nursery maintained in Nairobi, and were harvested as needed when plants were in early vegetative stages (3-6 wk old). The maize and sorghum were grown under the same conditions and received equal amounts of cow manure but no chemical fertilizer. From the third instar until pupation, larvae were fed with pieces of fresh maize and sorghum stems from more mature plants $(6-10 \mathrm{wk}$ old $)$. The pieces of plant tissue ( $\approx 4 \mathrm{~cm}$ long, $1.5-2 \mathrm{~cm}$ in diameter) were washed in a $2 \%$ solution of commercially available bleach $(0.05 \%$ sodium hypochlorite) to kill any microbial contaminants originating from the field, and then dried. A preweighed piece of stem or whorl tissue was offered to a larva in a glass vial $(7.5 \mathrm{by} 2.5 \mathrm{~cm})$, 
Table 1. Mean fecundity $( \pm \mathrm{SD})$ of $C$. partellus and $C$. orichalcociliellus under different temperatures and relative humidities

\begin{tabular}{|c|c|c|c|c|c|c|}
\hline \multirow{3}{*}{ Temp, ${ }^{\circ} \mathrm{C}$} & \multicolumn{6}{|c|}{$\% \mathrm{RH}$} \\
\hline & \multicolumn{2}{|c|}{75} & \multicolumn{2}{|c|}{85} & \multicolumn{2}{|c|}{96} \\
\hline & C. partellus & C. orichalcociliellus & C. partellus & C. orichalcociliellus & C. partellus & $\overline{\text { C. orichalcociliellus }}$ \\
\hline 25 & $99.9 \pm 123.92 \mathrm{a}$ & $53.7 \pm 100.17 b$ & $126.0 \pm 108.02 \mathrm{a}$ & $73.9 \pm 96.40 \mathrm{~b}$ & $150.7 \pm 124.85 \mathrm{a}$ & $112.7 \pm 129.47 \mathrm{~b}$ \\
\hline 28 & $153.1 \pm 136.85 a$ & $69.4 \pm 97.64 b$ & $165.7 \pm 140.81 \mathrm{a}$ & $121.2 \pm 107.59 \mathrm{~b}$ & $144.4 \pm 113.10 \mathrm{a}$ & $101.3 \pm 114.04 \mathrm{~b}$ \\
\hline 31 & $128.9 \pm 133.12 \mathrm{a}$ & $101.3 \pm 125.47 \mathrm{a}$ & $126.0 \pm 142.22 \mathrm{a}$ & $105.2 \pm 150.87 \mathrm{a}$ & $113.8 \pm 132.02 \mathrm{a}$ & $135.3 \pm 171.05 \mathrm{a}$ \\
\hline
\end{tabular}

Within each relative humidity, means in the same row with different letters are significantly different $(P<0.05)$. F statistics as follows: $25^{\circ} \mathrm{C}, \mathrm{RH} 75, F=5.5 ; \mathrm{df}=1,148 ; P=0.0236 ; 25^{\circ} \mathrm{C}, \mathrm{RH} 85, F=12.9 ; \mathrm{df}=1,198 ; P=0.0004 ; 25^{\circ} \mathrm{C}, \mathrm{RH} 96, F=4.5 ; \mathrm{df}=1,198 ; P=$ $0.0356 ; 28^{\circ} \mathrm{C}, \mathrm{RH} 75, F=14.9 ; \mathrm{df}=1,148 ; P=0.0002 ; 28^{\circ} \mathrm{C}, \mathrm{RH} 85, F=6.3 ; \mathrm{df}=1,198 ; P=0.0128 ; 28^{\circ} \mathrm{C}, \mathrm{RH} 96, F=7.2 ; \mathrm{df}=1,198 ;$ $P=0.0079 ; 31^{\circ} \mathrm{C}, \mathrm{RH} 75, F=1.48 ; \mathrm{df}=1,148 ; P=0.2253 ; 31^{\circ} \mathrm{C}, \mathrm{RH} 85, F=1.0 ; \mathrm{df}=1,198 ; P=0.3158 ; 31^{\circ} \mathrm{C}, \mathrm{RH} 96, F=1.0 ; \mathrm{df}=$ 1,$198 ; P=0.3205$

which was then plugged with cotton wool. Larvae were allowed to feed for $4 \mathrm{~d}$ before replacing the diet. The injured plant tissue was weighed after all larval frass was carefully removed. Control pieces of stems and whorl tissue were kept in separate vials alongside the experimental diet to determine the weight loss from evaporation. The difference between the initial and final weights of the diet, after adjustment for weight loss from evaporation, indicated feeding by the larvae. The number of days taken for each larva to reach the pupal stage was recorded. Larvae that died or escaped before pupation were not included in the analysis. The experiments were initiated with $\approx 200$ larvae of each species, but only 101 and 48 C. partellus larvae and 91 and 20 C. orichalcociliellus larvae reached pupation in maize and sorghum, respectively. Experiments were conducted at $28^{\circ} \mathrm{C}$. Data were analyzed by ANOVA (PROC GLM, SAS Institute 1988) to detect any differences in the quantities of maize and sorghum consumed by C. partellus and C. orichalcociliellus on a daily basis and in a larval lifetime.

Developmental Time and Larval Survival. The larvae used in this experiment originated from colonies maintained on artificial diet (Ochieng et al. 1985). Three cultivated grass hosts-maize, Zea mays L.; sorghum, Sorghum bicolor (L.) Moench; and napier grass, Pennisetum purpureum Schumach., and two wild grass hosts, wild sorghum, Sorghum arundinaceum (Desv.) Stapf; and guinea grass, Panicum maximum Jacq. (Poaceae)-were infested with neonate larvae. The maize and sorghum plants used in this study were from the same plots as indicated above for the food consumption experiment. The other grasses were maintained in neighboring plots under the same growing conditions. First instars of each of the borer species were placed individually in glass vials on tender leaf whorl tissue. There were 16-21 replications for each stem borer-host plant-temperature combination, with each replication including seven larvae. From the third instar, larvae were reared on pieces of fresh stems until death or pupation. Larvae were maintained at temperatures of 25,28 and $31^{\circ} \mathrm{C}$ and a photoperiod of 12:12 (L:D) h. Stems and whorl tissue were changed every $4 \mathrm{~d}$. Developmental time and survival to pupation were recorded. ANOVA (PROC GLM, SAS Institute 1988) was performed to compare the larval developmental period between stem borers within each host plant-temperature combination, and be- tween plants within each stem borer-temperature combination. Only those larvae that survived to pupation were included in the analysis of developmental time. Survival to pupation was compared for each species between plants within a temperature, and between species in the same plant-temperature combination by ANOVA (PROC GLM, SAS Institute 1988). Proportional data were arsine square root transformed before analysis.

\section{Results}

Fecundity and Egg Survival. The mean number of eggs laid by C. partellus was always greater than that of C. orichalcociliellus at 25 and $28^{\circ} \mathrm{C}$ at different relative humidities, but at $31^{\circ} \mathrm{C}$, no difference was found in the number of eggs laid by the two species, irrespective of the relative humidity (Table 1 ). In most cases, higher numbers of C. partellus eggs were fertile and hatched into first instars compared with those of C. orichalcociliellus (Tables 2 and 3). Even at $31^{\circ} \mathrm{C}$, where there was no difference in the number of eggs laid between species, more C. partellus survived to first instar.

Food Consumption by Larvae. Chilo partellus consumed more maize $(F=39.82 ; \mathrm{df}=1,191 ; P=0.0001)$ and sorghum $(F=4.27 ; \mathrm{df}=1,66 ; P=0.0426)$ than C. orichalcociliellus on a daily basis (Fig. 1). In maize and sorghum, the developmental time for C. partellus was shorter than that of $C$. orichalcociliellus $(F=4.20$; $\mathrm{df}=1,191 ; P=0.0417$ for maize, $F=13.60 ; \mathrm{df}=1,66$; $P=0.0005$ for sorghum) (Fig. 2). Over these shorter developmental times, C. partellus consumed more maize than C. orichalcociliellus $(F=20.25$; $\mathrm{df}=1,191$; $P=0.0001$ ), whereas both species consumed equal amounts of sorghum $(F=0.36 ; \mathrm{df}=1,66 ; P=0.5532)$ (Fig. 3). Comparisons of the quantities of maize and sorghum stems consumed by each stem borer species revealed that C. partellus consumed more maize than sorghum both on a daily basis $(F=42.96$; $\mathrm{df}=1,138$; $P=0.0001)$ and throughout the larval lifetime $(F=$ $11.83 ; \mathrm{df}=1,138 ; P=0.0008)$. C. orichalcociliellus also consumed more maize than sorghum on a daily basis $(F=34.69 ; \mathrm{df}=1,119 ; P=0.0001)$, but the quantities of maize and sorghum consumed by $C$. orichalcociliellus in a larval lifetime were not significantly different $(F=1.19 ; \mathrm{df}=1,119 ; P=0.2775)$. 
Table 2. Percentage egg fertility $( \pm \mathrm{SD})$ of $C$. partellus and $C$. orichalcociliellus under different temperatures and relative humidities

\begin{tabular}{|c|c|c|c|c|c|c|}
\hline \multirow{3}{*}{ Temp, ${ }^{\circ} \mathrm{C}$} & \multicolumn{6}{|c|}{$\% \mathrm{RH}$} \\
\hline & \multicolumn{2}{|r|}{75} & \multicolumn{2}{|c|}{85} & \multicolumn{2}{|r|}{96} \\
\hline & C. partellus & C. orichalcociliellus & C. partellus & C. orichalcociliellus & C. partellus & $\overline{\text { C. orichalcociliellus }}$ \\
\hline 25 & $43.2 \pm 40.88 \mathrm{a}$ & $33.6 \pm 30.39 a$ & $72.0 \pm 33.06 \mathrm{a}$ & $47.9 \pm 41.36 \mathrm{~b}$ & $63.7 \pm 38.45 a$ & $38.0 \pm 40.61 \mathrm{~b}$ \\
\hline 28 & $70.9 \pm 35.21 \mathrm{a}$ & $55.8 \pm 35.27 \mathrm{a}$ & $70.3 \pm 32.67 \mathrm{a}$ & $34.2 \pm 37.53 b$ & $74.3 \pm 34.80 \mathrm{a}$ & $59.7 \pm 39.06 b$ \\
\hline 31 & $59.8 \pm 39.12 \mathrm{a}$ & $35.3 \pm 35.51 \mathrm{~b}$ & $67.6 \pm 36.30 \mathrm{a}$ & $30.6 \pm 34.49 b$ & $70.6 \pm 36.63 \mathrm{a}$ & $30.0 \pm 37.40 \mathrm{~b}$ \\
\hline
\end{tabular}

Within each relative humidity, means in the same row with different letters are significantly different $(P<0.05)$. Values shown are untransformed. $F$ statistics as follows: $25^{\circ} \mathrm{C}, \mathrm{RH} 75, F=7.8 ; \mathrm{df}=1,148 ; P=0.0059 ; 25^{\circ} \mathrm{C}, \mathrm{RH} 85, F=18.3 ; \mathrm{df}=1,198 ; P=0.0001 ; 25^{\circ} \mathrm{C}$ $\mathrm{RH} 96, F=11.6 ; \mathrm{df}=1,198 ; P=0.0008 ; 28^{\circ} \mathrm{C}, \mathrm{RH} 75, F=13.8 ; \mathrm{df}=1,148 ; P=0.0003 ; 28^{\circ} \mathrm{C}, \mathrm{RH} 85, F=25.6 ; \mathrm{df}=1,198 ; P=0.0001$; $28^{\circ} \mathrm{C}, \mathrm{RH} 96, F=9.9 ; \mathrm{df}=1,198 ; P=0.0019 ; 31^{\circ} \mathrm{C}, \mathrm{RH} 75, F=9.35 ; \mathrm{df}=1,148 ; P=0.0027 ; 31^{\circ} \mathrm{C}, \mathrm{RH} 85, F=13.2 ; \mathrm{df}=1,198 ; P=$ $0.0003 ; 31^{\circ} \mathrm{C}, \mathrm{RH} 96, F=8.6 ; \mathrm{df}=1,198 ; P=0.0038$.

Larval Survival and Development. Survival of both stem borers at all temperatures was higher on maize than on other plants. In addition to maize, a few $C$. partellus survived at some temperatures on sorghum and wild sorghum, whereas $C$. orichalcociliellus survived in low numbers on sorghum, wild sorghum, napier grass, and guinea grass (Table 4). Developmental time from eclosion to pupation for C. partellus at $28^{\circ} \mathrm{C}$ was faster on maize than on sorghum. For $C$. orichalcociliellus, development was faster on maize and sorghum than on napier and guinea grasses at $28^{\circ} \mathrm{C}$, and faster on maize and sorghum than napier grass at $31^{\circ} \mathrm{C}$. In all cases where statistical comparisons were possible, C. partellus developed in a shorter time than C. orichalcociliellus (Table 5).

\section{Discussion}

At the lower temperatures tested $\left(25\right.$ and $\left.28^{\circ} \mathrm{C}\right), C$. partellus laid more eggs than $C$. orichalcociliellus. At the highest temperature, the mean number of eggs laid by the two species was similar. The fertility and hatchability of C. partellus eggs were higher than C. orichalcociliellus eggs under all conditions examined except at the lower temperature and humidity regimes, where no differences were found. Mean monthly temperatures in the southern coastal area of Kenya, where the displacement of C. orichalcociliellus by C. partellus is thought to be occurring, range from $\approx 24$ to $28^{\circ} \mathrm{C}$, and relative humidities range from $60-95 \%$ (Kenya Government 1991). Thus, our laboratory experiments suggest that the coastal climate may be generally more favorable for the reproduction of C. partellus than of
C. orichalcociliellus, and, therefore, a higher reproductive potential of the exotic over the native species may be one of the factors involved in the displacement process. However, the numbers of eggs laid by both species were low compared with earlier reports by Berger (1989) for C. partellus and Delobel (1975) for C. orichalcociliellus, suggesting that our rearing conditions may not have been optimal.

Chilo partellus consumed more maize and sorghum on a daily basis than C. orichalcociliellus, and more maize than C. orichalcociliellus during the larval stage, but equal amounts of sorghum. These findings suggest that C. partellus may be a more voracious feeder, and thus may cause greater damage to maize than $C$. orichalcociliellus. It would be interesting to examine whether this difference observed in the laboratory occurs in the field.

Larval survival was generally quite low on all the plants tested, possibly because of handling when changing the diet every few days. However, survival was clearly much higher for both stem borers in maize than in any of the other cultivated or wild grasses. Similarly, Shanower et al. (1993) compared life table parameters of the stem borers S. calamistis and Eldana saccharina (Walker) (Lepidoptera: Pyralidae) Walker feeding on maize and wild grasses, and found that larval survival was highest on maize. Maize is an exotic plant in Africa, which has been intensively cultivated in East Africa only in the last 100 or so years (Purseglove 1972, Dowswell et al. 1996). It appears that the introduction of this plant, which has no evolutionary history with Old World stem borers, has provided a highly nutritional resource for stem borers, which may

Table 3. Percentage egg hatchability ( \pm SD) of $C$. partellus and $C$. orichalcociliellus at different temperatures and relative humidities

\begin{tabular}{|c|c|c|c|c|c|c|}
\hline \multirow{3}{*}{ Temp, ${ }^{\circ} \mathrm{C}$} & \multicolumn{6}{|c|}{$\% \mathrm{RH}$} \\
\hline & \multicolumn{2}{|r|}{75} & \multicolumn{2}{|r|}{85} & \multicolumn{2}{|c|}{96} \\
\hline & C. partellus & C. orichalcociliellus & C. partellus & C. orichalcociliellus & C. partellus & C. orichalcociliellus \\
\hline 25 & $34.1 \pm 36.64 \mathrm{a}$ & $22.9 \pm 27.93 \mathrm{a}$ & $61.7 \pm 33.38 \mathrm{a}$ & $36.9 \pm 35.46 \mathrm{~b}$ & $52.2 \pm 35.59 \mathrm{a}$ & $32.5 \pm 36.90 \mathrm{~b}$ \\
\hline 28 & $57.6 \pm 33.30 \mathrm{a}$ & $42.6 \pm 29.96 b$ & $58.0 \pm 31.97 \mathrm{a}$ & $25.9 \pm 29.89 b$ & $62.9 \pm 36.25 \mathrm{a}$ & $50.5 \pm 35.79 b$ \\
\hline 31 & $50.5 \pm 36.27 \mathrm{a}$ & $30.2 \pm 30.44 b$ & $58.0 \pm 34.00 \mathrm{a}$ & $20.9 \pm 25.19 b$ & $59.8 \pm 38.37 \mathrm{a}$ & $20.1 \pm 29.06 b$ \\
\hline
\end{tabular}

Within each relative humidity, means in the same row with different letters are significantly different $(P<0.05)$. Values shown are untransformed. $F$ statistics as follows: $25^{\circ} \mathrm{C}, \mathrm{RH} 75, F=2.2 ; \mathrm{df}=1,87 ; P=0.138 ; 25^{\circ} \mathrm{C}, \mathrm{RH} 85, F=18.5 ; \mathrm{df}=1,143 ; P=0.0001 ; 25^{\circ} \mathrm{C}$, $\mathrm{RH} 96, F=8.4 ; \mathrm{df}=1,143 ; P=0.0043 ; 28^{\circ} \mathrm{C}, \mathrm{RH} 75, F=4.8 ; \mathrm{df}=1,106 ; P=0.03 ; 28^{\circ} \mathrm{C}, \mathrm{RH} 85, F=38.3 ; \mathrm{df}=1,156 ; P=0.0001$; $28^{\circ} \mathrm{C}, \mathrm{RH} 96, F=5.9 ; \mathrm{df}=1,139 ; P=0.0164 ; 31^{\circ} \mathrm{C}, \mathrm{RH} 75, F=7.8 ; \mathrm{df}=1,94 ; P=0.0063 ; 31^{\circ} \mathrm{C}, \mathrm{RH} 85, F=57.6 ; \mathrm{df}=1,137 ; P=0.0001$; $31^{\circ} \mathrm{C}, \mathrm{RH} 96, F=23.7 ; \mathrm{df}=1,137 ; P=0.0001$. 


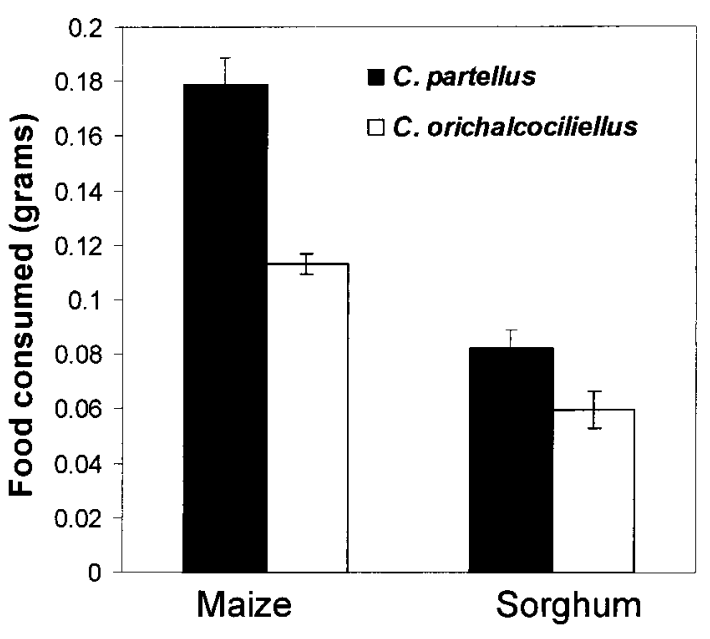

Fig. 1. Quantities of maize and sorghum consumed by larvae of C. partellus and C. orichalcociliellus on a daily basis (error bars represent the standard error).

have resulted in increased stem borer densities. Setamou et al. (1993) demonstrated that nitrogen and silica content in grasses influences the survival of the stem borer S. calamistis, with increased nitrogen promoting survival and silica adversely effecting survival. Although we did not quantify plant nutrient levels in the current study, the relative amounts of nitrogen and silica may provide an explanation for the differential survival in the grasses examined.

Chilo partellus and C. orichalcociliellus were able to develop on cultivated and wild sorghum, whereas napier grass and guinea grass supported the development of only C. orichalcociliellus. The ability of $C$. orichalcociliellus to complete development in two native grasses in which C. partellus did not survive, albeit

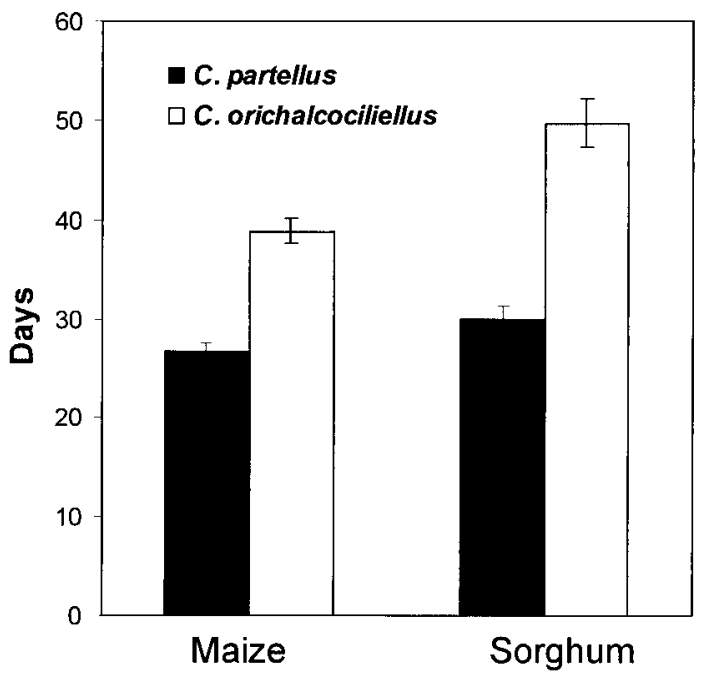

Fig. 2. Duration of larval development of C. partellus and C. orichalcociliellus reared in maize and sorghum at $28^{\circ} \mathrm{C}$ (error bars represent standard error).

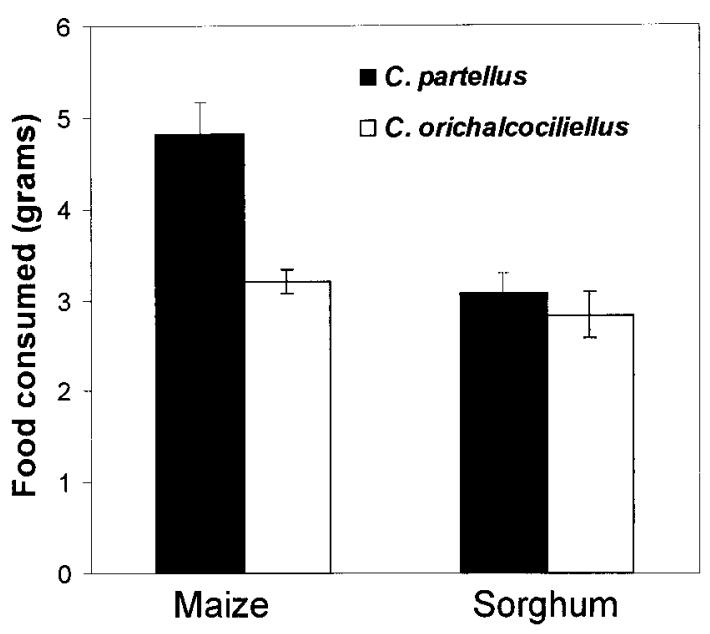

Fig. 3. Quantities of maize and sorghum consumed by $C$. partellus and C. orichalcociliellus during larval development (error bars represent the standard error).

survival was quite low, may give this species an advantage over C. partellus. Debach et al. (1978) suggested that if a reproductively inferior ecological homologue in a given habitat had an alternate host or a spatial refuge suitable only to itself, it could survive and coexist with the reproductively superior species. The differential survival in wild grasses may therefore be an important factor that has allowed C. orichalcociliellus to escape extirpation from the Kenya coast.

Kioko et al. (1995) reported a shorter larval developmental period of C. partellus than C. orichalcociliellus on an artificial diet, and Mbapila (1997) obtained similar results in maize. The current study, which showed a shorter larval developmental time of C. partellus compared with C. orichalcociliellus in maize and sorghum, confirms the previous studies on artificial diet and maize. The relatively faster development of $C$. partellus compared with C. orichalcociliellus may be an important factor in the displacement process.

It was fortuitous that three similar studies on maize stem borers (Mathez 1972, Warui and Kuria 1983, Overholt et al. 1994) were conducted in the same area of Kenya over a period from 1965 to 1992, which together recorded a dramatic shift in species abundance over time. In addition to Kenya, C. orichalcociliellus has been reported from Tanzania, Malawi, South Africa, and Madagascar (Bleszynski 1970), where C. partellus is also found (Harris 1990). Only in Madagascar is there some information on the interaction between the two species. C. partellus was first recorded in Madagascar in 1972, and by 1975 it had become a far more serious pest of maize and sorghum than C. orichalcociliellus (Delobel 1975). Unfortunately, density estimates of the two stem borers before and after the arrival of C. partellus are not available, so no conclusions can be made about displacement. However, it would seem likely that in Madagascar, and other areas where the distributions of $C$. orichalco- 
Table 4. Percentage survival of $C$. partellus and $C$. orichalcociliellus larvae to pupation reared on five grasses at three temperatures

\begin{tabular}{|c|c|c|c|c|c|c|}
\hline \multirow{2}{*}{ Temp, ${ }^{\circ} \mathrm{C}$} & \multirow{2}{*}{ Plant } & \multicolumn{2}{|c|}{ Survival } & \multirow{2}{*}{ F } & \multirow{2}{*}{$\mathrm{df}$} & \multirow{2}{*}{$P$} \\
\hline & & C. partellus (n) & C. orichalcociliellus $(n)$ & & & \\
\hline \multirow[t]{8}{*}{25} & Maize & $25.7(140) \mathrm{aA}$ & $27.9(147) \mathrm{aA}$ & 0.04 & 1,39 & 0.847 \\
\hline & Sorghum & $5.4(112) \mathrm{aB}$ & $4.1(147) \mathrm{aB}$ & 0.02 & 1,35 & 0.900 \\
\hline & Napier & $0.0(140) \mathrm{aB}$ & $0.7(147) \mathrm{aB}$ & 0.95 & 1,39 & 0.335 \\
\hline & Wild sorghum & $0.0(126) \mathrm{aB}$ & $2.1(140) \mathrm{aB}$ & 3.01 & 1,36 & 0.091 \\
\hline & Guinea grass & $0.0(126) \mathrm{B}$ & $0.0(147) \mathrm{B}$ & - & - & - \\
\hline & $F$ & 32.4 & 17.3 & & & \\
\hline & df & 4,87 & 4,99 & & & \\
\hline & $P$ & 0.0001 & 0.0001 & & & \\
\hline \multirow[t]{8}{*}{28} & Maize & $27.1(140) \mathrm{aA}$ & $28.6(147) \mathrm{aA}$ & 0.25 & 1,39 & 0.621 \\
\hline & Sorghum & $5.6(126) \mathrm{aB}$ & $3.4(147) \mathrm{aB}$ & 0.32 & 1,37 & 0.575 \\
\hline & Napier & $0.0(140) \mathrm{aB}$ & $1.7(147) \mathrm{aB}$ & 2.00 & 1,39 & 0.165 \\
\hline & Wild sorghum & $2.4(126) \mathrm{aB}$ & $0.0(147) \mathrm{aB}$ & 3.98 & 1,37 & 0.053 \\
\hline & Guinea grass & $0.0(126) \mathrm{aB}$ & $0.7(147) \mathrm{aB}$ & 0.85 & 1,37 & 0.362 \\
\hline & $F$ & 14.8 & 32.9 & & & \\
\hline & $\mathrm{df}$ & 4,89 & 4,100 & & & \\
\hline & $P$ & 0.0001 & 0.0001 & & & \\
\hline \multirow[t]{8}{*}{31} & Maize & $29.3(140) \mathrm{aA}$ & 19.7 (147)aA & 1.07 & 1,39 & 0.307 \\
\hline & Sorghum & $1.6(126) \mathrm{aB}$ & $0.7(147) \mathrm{aB}$ & 0.13 & 1,37 & 0.716 \\
\hline & Napier & $0.0(140) \mathrm{aB}$ & $0.7(147) \mathrm{aB}$ & 0.95 & 1,39 & 0.335 \\
\hline & Wild sorghum & $0.0(126) \mathrm{B}$ & $0.0(147) \mathrm{B}$ & - & - & - \\
\hline & Guinea grass & $0.0(126) \mathrm{B}$ & $0.0(147) \mathrm{B}$ & - & - & - \\
\hline & $F$ & 32.0 & 35.4 & & & \\
\hline & $\mathrm{df}$ & 4,89 & 4,100 & & & \\
\hline & $P$ & 0.0001 & 0.0001 & & & \\
\hline
\end{tabular}

Values followed by the same lower case letter in the same row are not significantly different (Student-Newman-Keuls multiple range test, $P>0.05)$. Values followed by the same upper case letter in the same column within each temperature are not significantly different (Student-Newman-Keuls multiple range test, $P>0.05$ ). Statistical analysis was performed on arcsine square root of the proportion surviving. Untransformed values are presented in the table.

ciliellus and C. partellus overlap, partial displacement has or will occur.

The displacement of native species by C. partellus has taken place not only with C. orichalcociliellus, but also with at least one other native stem borer. Kfir (1997) sampled stem borers in maize and sorghum in the eastern Highveld region of South Africa from 1985 to 1992 and presented clear evidence of a partial dis-

Table 5. Developmental time $( \pm \mathrm{SD})$ of $C$. partellus and $C$. orichalcociliellus larvae to pupation reared on five grasses at three temperatures

\begin{tabular}{|c|c|c|c|c|c|c|}
\hline \multirow{2}{*}{ Temp, ${ }^{\circ} \mathrm{C}$} & \multirow{2}{*}{ Plant } & \multicolumn{2}{|c|}{ Developmental time, $\mathrm{d}$} & \multirow{2}{*}{$F$} & \multirow{2}{*}{$\mathrm{df}$} & \multirow{2}{*}{$P$} \\
\hline & & C. partellus $(n)$ & C. orichalcociliellus $(n)$ & & & \\
\hline \multirow[t]{8}{*}{25} & Maize & $29.8 \pm 4.7 \mathrm{bA}$ & $36.1 \pm 10.0 \mathrm{aA}$ & 11.8 & 1,75 & 0.0010 \\
\hline & Sorghum & $31.3 \pm 5.6 \mathrm{bA}$ & $41.5 \pm 9.2 \mathrm{aA}$ & 5.3 & 1,10 & 0.0441 \\
\hline & Napier & - & $36.0 \mathrm{~A}$ & - & - & - \\
\hline & Wild sorghum & - & $54.0 \mathrm{~A}$ & - & - & - \\
\hline & Guinea grass & - & - & - & - & - \\
\hline & $F$ & 0.52 & 3.31 & & & \\
\hline & df & 1,40 & 3,47 & & & \\
\hline & $P$ & 0.476 & 0.028 & & & \\
\hline \multirow[t]{8}{*}{28} & Maize & $23.2 \pm 3.7 \mathrm{bB}$ & $28.7 \pm 11.4 \mathrm{aB}$ & 23.1 & 1,78 & 0.0001 \\
\hline & Sorghum & $32.4 \pm 6.3 \mathrm{aA}$ & $39.8 \pm 16.1 \mathrm{aA}$ & 1.3 & 1,10 & 0.2905 \\
\hline & Napier & - & $60.0 \pm 0.0 \mathrm{~A}$ & - & - & - \\
\hline & Wild sorghum & $32.0 \pm 7.8 \mathrm{~A}$ & - & - & - & - \\
\hline & Guinea grass & - & 34.0 & - & - & - \\
\hline & $F$ & 17.27 & 13.49 & & & \\
\hline & df & 2,45 & 3,46 & & & \\
\hline & $P$ & 0.0001 & 0.0001 & & & \\
\hline \multirow[t]{8}{*}{31} & Maize & $22.7 \pm 4.7 \mathrm{bA}$ & $28.8 \pm 11.4 \mathrm{aB}$ & 9.5 & 1,68 & 0.0030 \\
\hline & Sorghum & $27.0 \mathrm{~A}$ & $29.0 \pm 0.0 \mathrm{~B}$ & - & - & - \\
\hline & Napier & - & $83.0 \mathrm{~A}$ & - & - & - \\
\hline & Wild sorghum & - & - & - & - & - \\
\hline & Guinea grass & - & - & - & - & - \\
\hline & $F$ & 3.48 & 10.99 & & & \\
\hline & $\mathrm{df}$ & 1,41 & 2,28 & & & \\
\hline & $P$ & 0.069 & 0.0003 & & & \\
\hline
\end{tabular}

Values followed by the same lower case letter in the same row are not significantly different (Student-Newman-Keuls multiple range test, $P>0.05)$. Values followed by the same upper case letter in the same column within each temperature are not significantly different (Student-Newman-Keuls multiple range test, $P>0.05$ ). 
placement of Busseola fusca (Fuller) by the invasive species. What is particularly striking about the South African displacement is the elevation at which it occurred $(1,600 \mathrm{~m})$, because it was previously thought that C. partellus was restricted to warmer low and mid-elevation areas (Ingram 1958, Nye 1960, Sithole 1990). Kfir (1997) speculated that a shorter time requirement for diapause termination of C. partellus compared with B. fusca was one of the mechanisms involved in the displacement.

The factors examined in the current study-fecundity, survival and developmental rate-may be at least partially responsible for the displacement of $C$. orichalcociliellus by $C$. partellus. The ability of $C$. orichalcociliellus to survive in two native grasses in which C. partellus did not develop is a possible explanation for the incomplete displacement. Both grasses are widespread in Africa, suggesting that C. orichalcociliellus may have a refuge from competition with $C$. partellus elsewhere.

Other factors, not addressed in the current study, also could play an important role in the displacement, such as direct competition within the plant, the intensity of aestivation, and dispersal capabilities of the two species. An important external factor that may influence the abundance of the two species is the diversity and abundance of various host grasses in the coastal area of Kenya. The amount of land devoted to maize production in Kenya doubled from $\approx 0.75$ million hectares in 1961 to 1.5 million ha in 1998 (FAO 1999), and it would be reasonable to speculate that at least part of the increase in land area devoted to maize has been at the expense of wild, large-stemmed grasses. The present work suggests that this change may favor the occurrence of C. partellus over $C$. orichalcociliellus because C. partellus had a shorter developmental time in maize, and C. orichalcociliellus survived in more native grasses than C. partellus. However, the production of napier grass as a livestock forage also has increased in Kenya during the same period (Kariuki 1998), which may tend to favor $C$. orichalcociellus. In addition to a change in the species diversity of grasses, a shift in the varieties of maize grown, along with a change in fertilizer use, could impact the relative abundance of the two Chilo species. However, this does not appear likely because only an estimated $38 \%$ of farmers in the Coast Province grow improved varieties, and even fewer apply chemical fertilizers (Karanja et al. 1998).

This work is part of an ongoing project on classical biological control of C. partellus in eastern and southern Africa. An old association parasitoid of C. partellus, Cotesia flavipes Cameron (Hymenoptera: Braconidae), was introduced into Kenya from India and Pakistan in 1993, and is now firmly established (Overholt 1998). If C. partellus is displacing C. orichalcociliellus, as we believe, then a reduction in the density of $C$. partellus could lead to a resurgence of $C$. orichalcociliellus. However, laboratory tests showed that $C$. flavipes was attracted to, and would accept for oviposition, not only C. partellus but also C. orichalcociliellus and S. calamistis, although the suitability of the native species for parasitoid development was slightly inferior to that of C. partellus (Ngi-Song et al. 1995). Moreover, Ngi-Song et al. (1996) found that C. flavipes was attracted to odors from uninfested maize, sorghum, and napier grass, and even more attracted to the same three grasses infested with C. partellus, $C$. orichalcociliellus, or S. calamistis, suggesting that in the field, the parasitoid would search for a variety of stem borer-host plant combinations. Based on these laboratory findings, we predict that $C$. flavipes will search equally efficiently for the exotic and native stem borers in cultivated and noncultivated host plants; thus, an overall suppression of stem borer densities is likely. However, if the parasitoid differentially attacks the exotic stem borer, an increase in densities of the native stem borers may occur. Other African stem borers, such as B. fusca and E. saccharina, are attractive and acceptable for oviposition by $C$. flavipes but are not suitable for its development (Overholt et al. 1997). In areas where these stemborers are abundant, it seems unlikely that $C$. flavipes will establish. However, if $C$. partellus has displaced unsuitable native stem borers from some areas in Africa (as appears to be occurring at some locations in South Africa (Kfir 1997), then the parasitoid may initially establish. As densities of $C$. partellus decrease in response to increased mortality by natural enemies, a resurgence of the unsuitable native species may occur, which could in turn result in a decrease in the abundance, or complete extirpation, of C. flavipes.

\section{References Cited}

Alghali, A. M. 1985. The spotted stemborer, Chilo partellus (Swinhoe) (Lepidoptera: Pyralidae). and its principle host, sorghum. Insect Sci. Appl. 6: 315-322.

Ampofo, J.K.O., K. N. Saxena, J. G. Kibuka, and E. O. Nyangiri. 1986. Evaluation of some maize cultivars for resistance to the stem borer, Chilo partellus (Swinhoe) in western Kenya. Maydica 31: 379-389.

Berger, A. 1989. Egg weight, batch size and fecundity of the spotted stalk borer, Chilo partellus (Swinhoe) (Lepidoptera:Pyralidae), in relation to weight of females and time of oviposition. Entomol. Exp. Appl. 50: 199-207.

Bleszynski, S. 1970. A revision of the world species of Chilo Zincken (Lepidoptera: Pyralidae). Bull. Br. Mus. (Nat. Hist.) Entomol. 25: 101-195.

Debach, P., and L. A. Sundby. 1963. Competitive displacement between ecological homologues. Hilgardia 34: 105166.

Debach, P., R. M. Hendrickson, Jr., and M. Rose. 1978. Competitive displacement: extinction of the yellow scale, Aonidiella citrina (Coq.) (Homoptera:Diaspididae), by its ecological homologue the California red scale, Aonidiella aurantii (Mask.) in southern Califormia. Hilgardia 46: 1-35.

Delobel, A. 1975. Chilo orichalcociliellus Strand (Lepidoptera: Pyralidae) Foreur des tiges du sorgho et du mais a Madagascar 11. Premieres donnees biologiques. ORSTOM Ser. Biol. 10: 11-16.

Dowswell, C. R., R. L. Paliwal, and R. P. Cantrell. 1996. Maize in the third world. Westview, Boulder, CO.

FAO. 1999. FAOSTAT agricultural data (http://apps. fao.org/cgi-bin/nph-b.pl?subset = agriculture). 
Harris, K. M. 1990. Bioecology of Chilo species. Insect Sci. Appl. 11: 467-477.

Ingram, W. R. 1958. The lepidopterous stalk borers associated with Graminae in Uganda. Bull. Entomol. Res. 49: 367-783.

Karanja, D. D., T. S. Jayne, and P. Strasberg. 1998. Maize productivity and impact of market liberalization in Kenya. Proceeding of a conference on strategies for raising smallholder agricultural productivity and welfare, Egerton University/Tegemeo Institute of Agricultural. Policy and Development, 24 November 1998, Nairobi, Kenya.

Kariuki, J. 1998. The potential of improving napier grass under smallholder dairy farmers' condition in Kenya. Ph.D. disseration, Wageningen Agricultural University. Wageningen, The Netherlands.

Kenya Government. 1991. National atlas of Kenya. Survey of Kenya. Kenya Government, Nairobi.

Kfir, R. 1997. Competitive displacement of Busseola fusca (Lepidoptera: Noctuidae) by Chilo partellus (Lepidoptera: Pyralidae). Ann. Entomol. Soc. Am. 90: 619-624.

Kioko, E. N., W. A. Overholt, and J. M. Mueke. 1995. Larval development in Chilo orichalcociliellus and Chilo partellus: a comparative study in the laboratory, pp. 191-198. In Proceedings, 10th Meeting and Scientific Conference of the African Association of Insect Scientists, 5-10th September 1993, Mombasa. ICIPE Science Press, Nairobi, Kenya.

Khan, Z. R., P. Chiliswa, K. Ampong-Nyarko, L. E. Smart, A. Polaszek, J. Wandera, and M. A. Mulaa. 1997. Utilization of wild gramineous plants for management of cereal stemborers in Africa. Insect Sci. Appl. 17: 143-150.

Kumar, H., and K. N. Saxena. 1985. Oviposition by Chilo partellus (Swinhoe) in relation to its mating, diurnal cycle and certain non-plant surfaces. Appl. Entomol. Zool. 20: $18-21$.

Mathez,F.C. 1972. Chilo partellus (Swinhoe), Chilo orichalcociliellus Strand (Lepidoptera:Crambidae), and Sesamia calamistis (Hampson) (Lepidoptera:Noctuidae) on maize in the Coast Province, Kenya. Mitt. Schweiz. Entomol. Ges. 45: 267-289.

Mbapila, J. C. 1997. Comparative seasonal adaptation of $\mathrm{Co}-$ tesia flavipes Cameron and Cotesia sesamiae (Cameron) (Hymenoptera: Braconidae) to Chilo partellus Swinhoe (Lepidoptera: Pyralidae) on the Kenya coast. Ph.D dissertation, University of Dar-Es-Salaam, Tanzania.

Ngi-Song, A. J., W. A. Overholt, and J. N. Ayertey. 1995. Suitability of African gramineous stemborers for the development of Cotesia flavipes and Cotesia sesamiae (Hymenoptera: Braconidae). Environ. Entomol. 24: 978-984.

Ngi-Song, A. J., W. A. Overholt, P.G.N. Njagi, M. Dicke, J. A. Ayertey, and W. Lwande. 1996. Volatile infochemicals used in host and host habitat location by Cotesia flavipes Cameron and Cotesia sesamiae (Cameron) (Hymenop- tera: Braconidae), larval parasitoids of stemborers in Graminae. J. Chem. Ecol. 22: 307-323.

Nye, I.W.B. 1960. The insect pests of graminaceous crops in East Africa. Colonial Research Study No. 31. Her Majesty's Stationary Office, London.

Ochieng, R. S., F. O. Onyango, and M.D.O. Bungu. 1985. Improvement of techniques for mass culture of Chilo partellus (Swinhoe). Insect Sci. Appl. 6: 425-428.

Overholt, W. A., K. Ogedah, and P. M. Lammers. 1994. Distribution and sampling of Chilo partellus (Swinhoe) (Lepidoptera:Pyralidae) in maize and sorghum at the Kenya coast. Bull. Entomol. Res. 84: 367-378.

Overholt, W. A., A. J. Ngi-Song, C. O. Omwega, S. W. KimaniNjogu, J. Mbapila, M. N. Sallam, and V. Ofomata. 1997. A review of the introduction and establishment of Cotesia flavipes Cameron in East Africa for biological control of cereal stemborers. Insect Sci. Appl. 17: 79-88.

Overholt, W. A. 1998. Biological control, pp. 349-362. In A. Polaszek [ed.], African cereal stem borers: economic importance, taxonomy, natural enemies and control. CAB, Wallington, Oxon, UK.

Purseglove, J. W. 1972. Tropical crops- monocotyledons. Longman, London.

SAS Institute. 1988. SAS/STAT user's guide, release 6.03 edition. SAS Institute, Cary, NC.

Seshu Reddy, K. V. 1989. Sorghum stem borer in eastern Africa, pp. 33-40. In Proceedings, International workshop on sorghum stemborers, 17-20 November 1987, Patancheru, India, ICRISAT, Patancheru.

Setamou, M., F. Schulthess, N. A. Bosque-Pérez, and A. Thomas-Odjo. 1993. Effect of plant nitrogen and silica on the bionomics of Sesamia calamistis (Lepidoptera: Noctuidae). Bull. Entomol. Res 83: 405-411.

Shanower, T. G., F.M.S. Schulthess, and N. Bosque-Pérez. 1993. The effect of larval diet on the growth and development of Sesamia calamistis Hampson (Lepidoptera: Noctuidae) and Eldana saccharina Walker (Lepidoptera: Pyralidae). Insect Sci. Appl. 14: 681-685.

Sithole, S. Z. 1990. Status and control of the stem borer, Chilo partellus Swinhoe (Lepidoptera: Pyralidae) in southern Africa. Insect Sci. Appl. 11: 481-488.

Tams, W.H.T. 1932. New species of African Heterocera. Entomologist 65:1241-1249.

Warui, C. M., and J. N. Kuria. 1983. Population incidence and the control of maize stalk borer Chilo partellus (Swinhoe), Chilo orichalcociliellus Strand (Lepidoptera:Pyralidae) and Sesamia calamistis Hampson (Lepidoptera:Noctuidae) in Coast Province, Kenya. Insect Sci. Appl. 4: $11-18$.

Received for publication 11 June 1999; accepted 8 December 1999. 